change in either weight ${ }^{161 ;}$ or diet. ${ }^{1-19}$ All patients were studied under standard conditions after fasting for about 12 hours.

These preliminary findings suggest that CDCA is a potentially useful adjunct to clofibrate treatment. It remains to be seen whether the effect on serum lipids and bile is sustained. So far, CDCA has been free from appreciable toxic effects, although in some cases the dose has had to be reduced because of diarrhoea. Theoretical considerations suggesting hepatotoxicity have been disproved by clinical experience in dissolving gall stones.

Since CDCA reversed the deterioration in bile caused by clofibrate and improved serum lipid control it merits further study in the management of hyperlipidaemia.

This work was supported by a grant from Weddel Pharmaceuticals.

\author{
References \\ 1 Pertsemlidis, D, Panveiliwalla, D, and Ahrens, E H, Gastroenterology, \\ 1974, 66, 565
}

${ }^{2}$ Einarsson, K, Hellström, K, and Kallner, M, European fournal of Clinical Investigation, 1973, 3, 345.

${ }^{3}$ Coronary Drug Project Research Group, fournal of the American Medical Association, 1975, 231, 360.

4 Coronary Drug Project Research Group, New England fournal of Medicine, 1977, 296, 1185.

${ }^{5}$ Cooper, J, Geizerova, H, and Oliver, M H, Lancet, 1975, 1, 1083.

${ }^{6}$ Mok, H Y I, Bell, G D, and Dowling, R H, Lancet, 1974, 2, 253.

Thistle, J L, et al, American fournal of Digestive Diseases, 1977, 22, 1.

${ }^{8}$ Bateson, M C, et al, Gut, 1977, 18, 599.

${ }^{9}$ Admirand, W, and Small, D M, fournal of Clinical Investigation, 1968, 47, 1043.

10 Thomas, P T, and Hofmann, A F, Gastroenterology, 1973, 65, 698

${ }^{11}$ Holzbach, R T, et al, fournal of Clinical Investigation, 1973, 52, 1467.

${ }^{12}$ Hegardt, F G, and Dam, H, Zeitschrift für Ernährungswissenschaft, 1971, $10,223$.

${ }^{13}$ Bateson, M C, et al, Gut, 1976, 17, 814.

${ }_{14}$ Miller, N E, and Nestel, P J, Lancet, 1974, 2, 929.

15. Bateson, M C, et al, British fournal of Clinical Pharmacology, 1978, 5, 249.

${ }^{16}$ Miettinen, T A, Circulation, 1971, 44, 842.

17 Bennion, L J, and Grundy, S M, fournal of Clinical Investigation, 1975, 56, 996.

18 Watanabe, N, Gimbel, N S, and Johnston, C G, Archives of Surgery, $1962,85,136$

${ }^{19}$ Grundy, S M, fournal of Clinical Investigation, 1975, 55, 269

(Accepted 24 February 1978)

\title{
Stigmata of recent haemorrhage in diagnosis and prognosis of upper gastrointestinal bleeding
}

\author{
D N FOSTER, K J A MILOSZEWSKI, M S LOSOWSKY
}

British Medical fournal, 1978, 1, 1173-1177

\section{Summary and conclusions}

In 277 consecutive episodes of suspected upper gastrointestinal bleeding, lesions bearing stigmata of recent haemorrhage (stigmata) were found by endoscopy in $110(47 \%)$ out of 233 patients who were judged to have bled; $78(33 \%)$ had lesions without stigmata, and in 45 $(19 \%)$ no lesion was seen. Results in 176 entirely unselected admissions for upper gastrointestinal bleeding were similar.

Forty-eight chronic duodenal and 41 chronic gastric ulcers were identified by endoscopy. Stigmata were found in $27(56 \%)$ and $33(80 \%)$ of these cases respectively. Sixteen patients had multiple lesions, and in $12(75 \%)$ the presence of stigmata permitted diagnosis of the source of the haemorrhage. Stigmata were more likely to be seen in cases of duodenal ulcer, Mallory-Weiss lesions, and oesophageal varices when endoscopy was performed within 12 hours of bleeding, but were as common in cases of gastric ulcer after longer intervals.

In the absence of stigmata one out of 21 patients with duodenal ulcer had further haemorrhage and one other needed emergency surgery; no patient with gastric ulcer

University Department of Medicine, St James's Hospital, Leeds LS9 7TF

D N FOSTER, MB, MRCP, senior registrar (now consultant physician, Birch Hill Hospital, Rochdale, Lancs)

K J A MILOSZEWSKI, BSC, MRCP, senior lecturer and honorary consultant physician

M S LOSOWSKY, MD, FRCP, professor of medicine had further haemorrhage or needed emergency surgery. In contrast, when stigmata were present 15 of the 27 patients with duodenal ulcer $(56 \%)$ had further haemorrhage and $17(63 \%)$ needed emergency surgery; of the 33 patients with gastric ulcer, $10(30 \%)$ had further haemorrhage and $15(45 \%)$ required emergency surgery. Superficial mucosal lesions may have been the source of haemorrhage when an ulcer unmarked by stigmata was seen at endoscopy. Stigmata were superior to any other single factor or combination of factors in predicting rebleeding and the need for emergency surgery.

\section{Introduction}

Endoscopy is considered to be the best means of identifying the source of bleeding in upper gastrointestinal haemorrhage. ${ }^{1-8}$ Evaluation of reported diagnostic accuracy is difficult since criteria for accepting a lesion as the source of bleeding are often not stated ${ }^{7-13}$ and the selection of patients is often not explicit. ${ }^{1012}$ The usefulness of emergency endoscopy is difficult to assess since most reports document the interval before endoscopy from the time of admission ${ }^{14-17}$ rather than from the time of the first symptoms of bleeding. Patients who rebleed after admission have a significantly higher mortality ${ }^{18-23}$; many patients with peptic ulcer rebleed, ${ }^{18}{ }^{21-23}$ and there is no satisfactory way of identifying those at risk. We studied patients with special reference to these features in diagnosis, prognosis, and management.

\section{Patients and methods}

A consecutive series of 277 episodes of suspected upper gastrointestinal bleeding was managed by our unit during 38 months; 176 were unselected emergency admissions, and 101 were selected (from 
other units, other hospitals, outpatients, readmissions, and inpatients with bleeding complicating another illness). No patient with a history suggestive of haematemesis or melaena or both was excluded. Endoscopy was performed as soon as practicable after resuscitation, intravenous diazepam and atropine being used for premedication. A form was completed for each episode of bleeding, recording past and present history, physical findings, interval from first symptom of bleeding, and mode of admission. Endoscopic findings were recorded, and the presence of blood in the upper gastrointestinal tract was noted. This information, with details of management and outcome of the episode, was later transferred to punch cards. On completion of the study we reviewed the 89 patients found by endoscopy to have chronic peptic ulcers to see whether the presence of stigmata was related to the subsequent occurrence of further haemorrhage and emergency surgery.

Further haemorrhage was defined as further fresh haematemesis or melaena or a change in pulse, blood pressure, and haemoglobin concentration sufficient to leave no clinical doubt. Emergency surgery was defined as surgery within three days of admission, usually for rebleeding; five patients with duodenal ulcer and six with gastric ulcer, however, underwent emergency surgery on account of age, previous episodes of upper gastrointestinal haemorrhage, perforation, magnitude of haemorrhage, or general condition. A lesion was accepted as the source of bleeding only when one or more of the following stigmata were observed: (a) fresh bleeding from the lesion; (b) fresh or altered blood clot or black slough adherent to the lesion; (c) a vessel protruding from the base or margin of an ulcer. Reflux of blood through a narrowed pylorus too small to admit the endoscope was not accepted as proof of a bleeding duodenal ulcer as the lesion itself could not be seen.

Statistical evaluations were carried out with the $\%^{2}$ test, Yates's correction being applied for small numbers, ${ }^{24}$ and Fisher's exact test.

\section{Results}

Endoscopy was performed in 245 of the 277 episodes $\left(88^{\circ}\right)$. Reasons for failure were refusal (10), non-cooperation (3), pregnancy (2), terminal disease (4), psychiatric disorder (3), death from exsanguination before endoscopy (2), patients with haemophilia presenting long after the bleeding episode (7), and omission (1).

\section{TIMING OF ENDOSCOPY}

In 109 cases $(45 \%)$ endoscopy was performed within six hours, in $147(60 \%)$ within 12 hours, and in $208(85 \%)$ within 24 hours of admission; owing to delay before admission, however, in only 53 cases $(22 \%)$ was endoscopy performed within 12 hours of the first symptom of bleeding. Of the 109 patients who underwent endoscopy within six hours of admission, 50 had their first symptom of bleeding more than 24 hours earlier and 36 more than 48 hours earlier.

\section{DIAGNOSIS OF BLEEDING LESIONS}

Table I shows all lesions confirmed by endoscopy, radiology, surgery, and necropsy in the whole series of 277 episodes of suspected bleeding. Thirteen patients $\left(4 \cdot 7^{\circ} \%\right)$ were judged not to have bled. With the exclusion of these, potential bleeding lesions were identified in $188(81 \%$ of the 233 patients who underwent endoscopy, but in only $110(47 \%)$ were stigmata seen, $78(33 \%)$ having lesions without stigmata and $45\left(19^{\circ}\right)$ no lesion. The proportions were similar in the unselected group of 176 episodes: $77(50 \%)$ of the patients had lesions with stigmata, $46\left(30^{\circ}{ }_{0}\right)$ lesions without stigmata, and $30(20 \%)$ no lesion (10 did not bleed; 153 underwent endoscopy).

\section{STIGMATA}

Prevalence-Lesions bearing stigmata were seen in $34\left(69^{\circ}\right)$ of the patients who underwent endoscopy within 12 hours of the first symptom of bleeding and in about $40^{\circ}$ " thereafter (table II). Fig 1 shows the prevalences of stigmata in patients with duodenal and gastric ulcers, Mallory-Weiss lesions, and varices in relation to the interval between bleeding and endoscopy. All seren patients with duodenal ulcers endoscoped within 12 hours had stigmata. Stigmata were more likely to be seen after longer delays in cases of gastric ulcer than of other types of lesion.
Prognostic value in peptic ulcer-Altogether 48 duodenal and 41 gastric ulcers were identified by endoscopy, stigmata being seen in 27 $\left(56^{\circ}\right)$ and $33\left(80^{\circ}\right)$ of the cases respectively (table III). Among the patients with duodenal ulcers, $15\left(55 \cdot 6 \%_{0}\right)$ of the 27 with stigmata had further haemorrhage compared with $1\left(4.8^{\circ}{ }_{0}\right)$ of the remaindero

TABLE I-All lesions found by endoscopy and radiology and at surgery and necropsy in the total series of 277 episodes of upper gastrointestinal bleeding

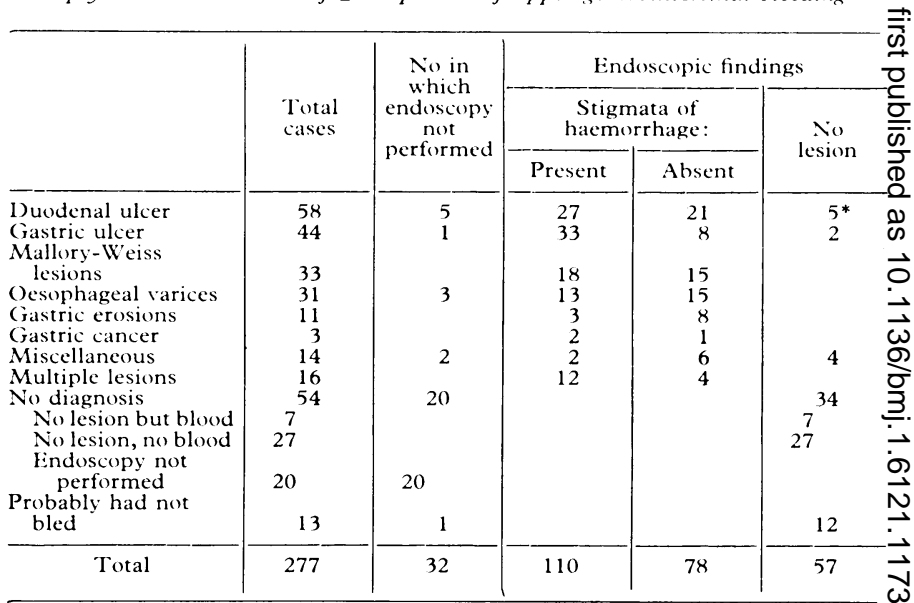

*In three patients the pylorus could not be intubated. Blood in the stomach and a duodenal ulcer were found at surgery in two cases and diagnosed radiologically. in one.

TABLE II-Prevalence of lesions bearing stigmata among the 233 patients subjected to endoscopy 12 hours or less to more than 48 hours after first symptom $\overrightarrow{0}$ of bleeding. Figures are numbers of patients (percentages in parentheses)

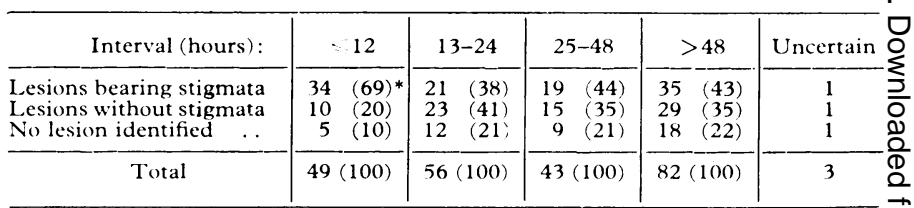

* $\mathrm{P}<0.001$ compared with other groups with lesions bearing stigmata.

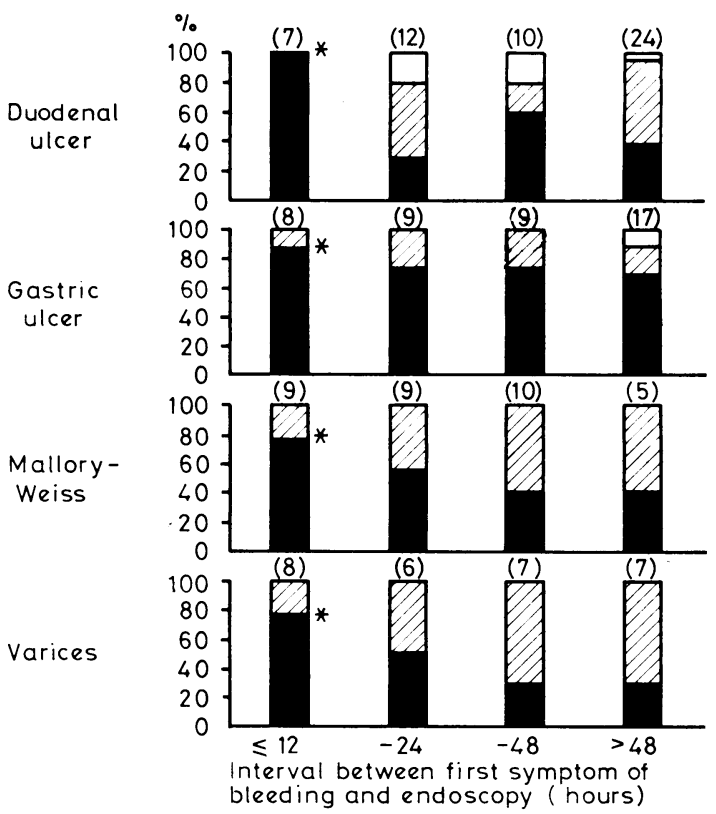

FIG 1-Percentage prevalences of stigmata in patients with four types of lesion endoscoped 12 hours or less to more than 48 hours after first symptome⿳亠 of bleeding. $\quad=$ Patients with lesions bearing stigmata. $\varnothing=$ Patients with $\rightleftharpoons$ lesions not bearing stigmata. $\square$... Patients with no lesion identified. (Numbers of patients in parentheses.)

*Prevalence of stigmata compared with prevalences in patients endoscoped at other times-Duodenal ulcer: $P=0 \cdot 006$. Gastric ulcer: $P=0 \cdot 295$. MalloryWeiss lesions: $\mathrm{P}=0.086$. Varices: $\mathrm{P}=0.057$. 
$(\mathrm{P}<0.001)$, and $17(63.0 \%)$ and $1\left(4.8{ }^{\circ}{ }_{0}\right)$ respectively needed emergency surgery $(P<0.001)$. (The one patient without stigmata underwent emergency surgery because of perforation.) Among the patients with gastric ulcers, $10\left(30.3^{\circ}{ }_{0}\right)$ of the 33 with stigmata had further haemorrhage and $15(45.5 \%)$ with stigmata needed emergency surgery; none of eight without stigmata had further haemorrhage $(\mathbf{P}=0.086)$ or needed emergency surgery $(\mathbf{P}=0.016)$ (table III). Thus of the 60 patients with peptic ulcers bearing stigmata, $25\left(41.7^{\circ}\right)$ had further haemorrhage and $32\left(53.3^{\circ}{ }_{0}\right)$ needed emergency surgery; and of the 29 without evidence of stigmata, $1\left(3.4^{\circ}\right)$ had further haemorrhage and $1\left(3.4^{\circ}{ }_{0}\right)$ needed emergency surgery $(P<0.001$ for each). Two patients with duodenal ulcers (both with stigmata) and seven with gastric ulcers (six with stigmata) died. Fig 2 shows the proportion of patients rebleeding and requiring emergency surgery related to stigmata, age, shock, and serious concomitant disease. Stigmata predicted the outcome better than any other factor. Drug and alcohol history, preoperative transfusion, lowest haemoglobin concentration, blood group, tachycardia, and hypotension were even less discriminating than any of the above factors. A scoring system of "poor prognostic factors":- (table IV) did not identify those at risk of further haemorrhage, emergency surgery, or death $(\mathbf{P}>0 \cdot 1)$.

Interval from onset of bleeding-There was no correlation between the timing of endoscopy after the first symptom of bleeding and the risk of further haemorrhage or emergency surgery and presence of active bleeding at endoscopy (five cases) in the patients with stigmata (table V).

TABLE III-Incidinces of further haemorrhage and emergency surgery in patients with duodenal and gastric ulcers with and without evidence of stigmata

\begin{tabular}{|c|c|c|c|c|c|c|}
\hline & \multicolumn{3}{|c|}{ Duodenal ulcers $(n=48)$} & \multicolumn{3}{|c|}{ Gastric ulcers $(n=41)$} \\
\hline & $\mid \begin{array}{c}\text { Stigmata } \\
(\mathrm{n}=27)\end{array}$ & $\begin{array}{c}\text { No } \\
\text { stigmata } \\
(\mathbf{n}=21)\end{array}$ & $\mathbf{P}$ & $\underset{(n=33)}{\text { Stigmata }}$ & $\begin{array}{c}\text { No } \\
\text { stigmata } \\
(\mathrm{n}=8)\end{array}$ & $\mathbf{P}$ \\
\hline $\begin{array}{l}\text { No ("\%) with further } \\
\text { haemorrhage }\end{array}$ & $15(55 \cdot 6)$ & $1(4 \cdot 8)$ & $<0.001$ & $10(30 \cdot 3)$ & 0 & 0.086 \\
\hline $\begin{array}{l}\text { No }(\%) \text { needing } \\
\text { emergency surgers. }\end{array}$ & $17(63.0)$ & $1(4 \cdot 8)^{*}$ & $<0.001$ & $15(45 \cdot 5)$ & 0 & 0.016 \\
\hline
\end{tabular}

*Surgery performed because of perforation.

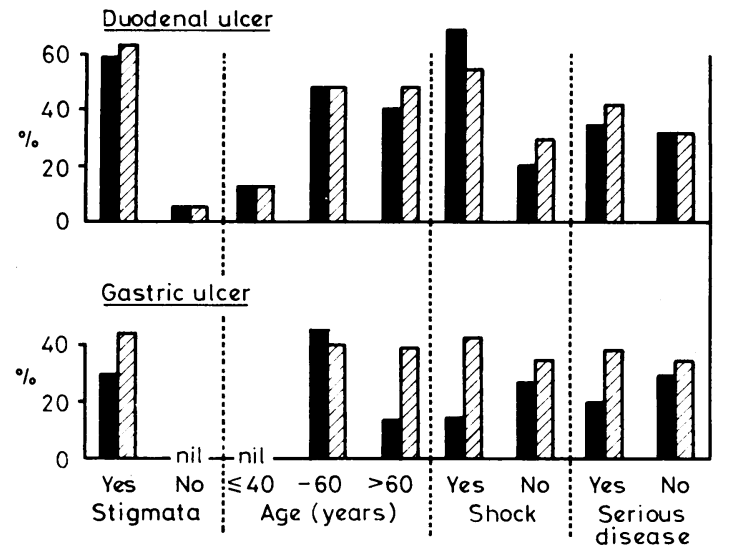

FIG 2-Proportions of patients with duodenal and gastric ulcers who had further haemorrhage or needed emergency surgery or both related to presence of stigmata, age, shock, and concomitant disease.

Further haemorrhage. $\nabla=$ Emergency surgery.

TABLE IV-Outcome in patients with duodenal and gastric ulcers in relation to scoring for six "poor prognostic factors" (Morgan et al ${ }^{25}$ )

\begin{tabular}{|c|c|c|c|c|c|c|c|}
\hline \multirow[t]{2}{*}{ Score } & \multirow{2}{*}{$\begin{array}{c}\text { No of } \\
\text { patients }\end{array}$} & \multicolumn{2}{|c|}{$\begin{array}{c}\text { Further } \\
\text { haemorrhage }\end{array}$} & \multicolumn{2}{|c|}{$\begin{array}{c}\text { Emergency } \\
\text { surgery }\end{array}$} & \multicolumn{2}{|c|}{ Deaths } \\
\hline & & No $(\%)$ & $\mathbf{P}$ & No $(\%)$ & $\mathbf{P}$ & No $(\%)$ & $\mathbf{P}$ \\
\hline \multicolumn{8}{|c|}{ Duodenal ulcer group } \\
\hline $\begin{array}{l}2 \text { or less } \\
3 \text { or more }\end{array}$ & $\begin{array}{l}28 \\
20\end{array}$ & $\begin{array}{r}10(36) \\
6(30)\end{array}$ & $0 \cdot 226$ & $\begin{array}{l}9(32) \\
9(45)\end{array}$ & 0.158 & $\begin{array}{l}0 \\
2(10)\end{array}$ & $0 \cdot 168$ \\
\hline \multicolumn{8}{|c|}{ Gastric ulcer group } \\
\hline $\begin{array}{l}2 \text { or less } \\
3 \text { or more }\end{array}$ & $\begin{array}{l}18 \\
23\end{array}$ & $\begin{array}{l}4(22) \\
6(26)\end{array}$ & 0.275 & $\begin{array}{r}5(28) \\
10(43)\end{array}$ & $0 \cdot 154$ & $\begin{array}{l}3(17) \\
4(17)\end{array}$ & 0.321 \\
\hline
\end{tabular}

TABLE $\mathrm{v}-$ Numbers of patients with ulcers bearing stigmata having further bleeding, emergency surgery, and active bleeding at endoscopy in relation to interval between endoscopy and first symptom of bleeding

\begin{tabular}{|c|c|c|c|c|}
\hline $\begin{array}{l}\text { Interval } \\
\text { (hours) }\end{array}$ & $\begin{array}{c}\text { No of } \\
\text { patients }\end{array}$ & $\begin{array}{c}\text { No with } \\
\text { further } \\
\text { haemorrhage }\end{array}$ & $\begin{array}{l}\text { No having } \\
\text { emergency } \\
\text { surgery }\end{array}$ & $\begin{array}{l}\text { No with active } \\
\text { bleeding at } \\
\text { endoscopy }\end{array}$ \\
\hline \multicolumn{5}{|c|}{ Duodenal ulcer group } \\
\hline $\begin{array}{c}12 \\
13-24 \\
25-48 \\
>48 \\
\text { Uncertain }\end{array}$ & $\begin{array}{l}7 \\
4 \\
6 \\
9 \\
1\end{array}$ & $\begin{array}{l}4 \\
1 \\
3 \\
6 \\
1\end{array}$ & $\begin{array}{l}3 \\
2 \\
4 \\
7 \\
1\end{array}$ & $\begin{array}{l}2 \\
1 \\
1 \\
1 \\
0\end{array}$ \\
\hline \multicolumn{5}{|c|}{ Gastric ulcer group } \\
\hline $\begin{array}{c}12 \\
13-24 \\
25-48 \\
>48\end{array}$ & $\begin{array}{r}7 \\
7 \\
7 \\
12\end{array}$ & $\begin{array}{l}2 \\
3 \\
2 \\
3\end{array}$ & $\begin{array}{l}4 \\
3 \\
2 \\
6\end{array}$ & \\
\hline
\end{tabular}

TABLE VI-Endoscopic diagnosis of source of haemorrhage in 16 patients with more than one lesion

\begin{tabular}{|c|c|c|c|}
\hline $\begin{array}{c}\text { Lesion with stigmata } \\
\text { of bleeding }\end{array}$ & $\begin{array}{c}\text { No of } \\
\text { patients }\end{array}$ & $\begin{array}{l}\text { Additional lesion with } \\
\text { no stigmata }\end{array}$ & $\begin{array}{c}\text { No of } \\
\text { patients }\end{array}$ \\
\hline Duodenal ulcer & 4 & $\begin{array}{l}\text { Varices } \\
\text { Varices and gastric ulcer } \\
\text { Oesophagitis and hiatus hernia } \\
\text { Mallory-Weiss lesion } \\
\text { Varices }\end{array}$ & $\begin{array}{l}1 \\
1 \\
1 \\
1 \\
1\end{array}$ \\
\hline Gastric ulcer & 4 & $\begin{array}{l}\text { Oesophageal ulcer } \\
\text { Oesophagitis and hiatus hernia } \\
\text { Mallory-Weiss lesion and erosions }\end{array}$ & $\begin{array}{l}1 \\
1 \\
1\end{array}$ \\
\hline Erosive gastritis & 1 & Varices & i \\
\hline $\begin{array}{l}\text { Mallory-Weiss } \\
\text { Axon-Clarke"1 }\end{array}$ & $\begin{array}{l}1 \\
1\end{array}$ & $\begin{array}{l}\text { Gastric ulcer } \\
\text { Duodenal and gastric ulcers }\end{array}$ & 1 \\
\hline Varices & 1 & Non-bleeding erosions & 1 \\
\hline None & 4\{ & $\begin{array}{l}\text { Duodenal and gastric ulcers } \\
\text { Gastric ulcer and Mallory-Weiss lesion }\end{array}$ & $\begin{array}{l}3 \\
1\end{array}$ \\
\hline
\end{tabular}

\section{MULTIPLE LESIONS}

Sixteen patients had multiple potential bleeding lesions (table VI). All but one were endoscoped more than 48 hours after the onset of bleeding; nevertheless, stigmata were seen in $12(75 \%)$.

\section{CAUSE OF BLEEDING IN PATIENTS WITH VARICES}

We treated 36 bleeding episodes in 32 patients with varices. Four were unselected and 32 selected admissions. In 17 cases $(48 \%)$ the patients were endoscoped within 24 hours of the onset of bleeding, and three of these were thought to have bled from another lesionnamely, erosions (one), gastric ulcer (one), and duodenal ulcer (one). Of the 16 endoscoped more than 24 hours after the onset of bleeding, two were thought to have bled from another lesion-namely, erosions (one) and duodenal ulcer (one). On three occasions endoscopy was not performed. Thus of the 33 patients investigated by endoscopy, at least $5(15 \%)$ probably bled from lesions other than varices.

Of the 28 patients with no lesion other than varices, nine were bleeding from the oesophagus at the time of endoscopy and four had other stigmata $(46 \%)$. In more than half we had to assume that bleeding had occurred from varices. Of those showing stigmata or actively bleeding, $9(69 \%)$ were endoscoped within the first 24 hours of bleeding. Of those without stigmata, $11(73 \%)$ were endoscoped more than 24 hours after the first symptom of bleeding.

\section{CASES WITH NO LESION OR BLOOD DETECTED}

In 27 cases no lesion or blood could be detected by endoscopy, yet we felt unable to conclude that the patients had not bled. Sixteen had a low haemoglobin concentration (11 of these were endoscoped more than 48 hours after the onset of symptoms): four had haemophilia; four gave a history suggestive of Mallory-Weiss syndrome, and endoscopy was later than 24 hours after the first symptoms in three; four were extensively investigated for recurrent bleeding and no diagnosis was made; four refused or were unsuitable for further investigation of probable lower gastrointestinal tract lesions. 
Eleven episodes were not associated with a fall in haemoglobin concentration (six of the patients were endoscoped more than 24 hours and three more than 48 hours after the onset of symptoms): six had a history suggestive of Mallory-Weiss syndrome, of whom two had occult blood in the stool and four were endoscoped more than 24 hours after haematemesis; two gave a convincing history of bleeding and previous ulcer surgery, one of whom had occult blood in the stools on seven occasions; two produced bloody vomit in front of a medical witness; one gave an unshakeable history of haematemesis.

\section{CASES WITH BLOOD BUT NO LESION DETECTED}

In seven cases blood was seen in the stomach but no localised lesion was identified. Two patients had non-erosive gastritis; one probably had an epistaxis, not an upper gastrointestinal haemorrhage; in one bleeding from the lower oesophagus was started (or restarted) by endoscopy; one had a recent history of gross alcohol excess; one had gastritis associated with a gastrojejunostomy; and one underwent surgery for continuing bleeding, and even at laparotomy no source was identified.

\section{Discussion}

The purpose of endoscopy in the investigation of gastrointestinal bleeding is to identify the source of haemorrhage. This may be achieved when a lesion is seen to bleed or, much more commonly, when it bears stigmata of recent haemorrhage. ${ }^{15}: 6$ Such findings constitute an advantage of endoscopy that is often ignored, lesions unmarked by stigmata being accepted as endoscopic diagnostic successes. ${ }^{1+5} \times 10-13$ The interval between the first symptoms of bleeding and endoscopy may influence the recognition of stigmata. Cotton et $a l^{1}$ found stigmata in $79^{\circ}$ ", of patients with ulcers examined "within 48 hours of bleeding" but in only one out of 21 cases examined thereafter. Allen et $a l^{10}$ reported a fall in diagnostic accuracy from $80^{\circ}{ }^{\circ}$ to $30^{\circ}$ ", when endoscopy was delayed more than 48 hours after admission, but criteria for acceptance that the lesion had bled were not specified. Forrest et al, ${ }^{15}$ routinely using gastric lavage, found $87^{\circ}$ " of patients examined within 24 hours of admission to have stigmata compared with $32^{\circ}{ }^{\circ}$, of those endoscoped after 48 hours. We found lesions with stigmata in $69^{\circ}$ " of patients endoscoped within 12 hours of the first symptom of bleeding and in about $40^{\circ}{ }_{0}$ thereafter, the fall in patients with gastric ulcers being less pronounced than in patients with other diagnoses.

Much of the delay between the onset of bleeding and endoscopy occurs before admission and is unavoidable. Our results suggest that the critical interval may be shorter than previously suspected. ${ }^{110}$

When endoscopy was performed more than 12 hours after the onset of bleeding not only was the proportion of lesions without stigmata greater but there was a doubling of the proportion of cases without a diagnosis. Similarly, Sandlow et $a l^{27}$ found a halving in the proportion of patients bleeding from superficial lesions and a doubling of cases with no diagnosis in the group randomised to endoscopy a week after admission rather than at once. Earlier endoscopy may not only increase definitive diagnoses but may also change their apparent relative frequency.

Of our 34 patients without a diagnosis, $22\left(65^{\circ}{ }_{11}\right)$ were endoscoped more than 24 hours after the first symptom; 10 gave a history suggestive of Mallory-Weiss syndrome: possibly these and others had bled from superficial lesions that were not obvious by the time of endoscopy. Of the 110 patients in whom a lesion with stigmata was identified, $55\left(50^{\circ}{ }_{11}\right)$ were endoscoped within 24 hours and $74\left(67^{\circ}{ }_{0}\right)$ within 48 hours of the first symptom of bleeding. In patients with multiple lesions, despite delay of more than 48 hours in all but one, stigmata were seen in $75^{\circ}{ }_{0}$ (12 cases), but a third of these were gastric ulcers. As in patients with gastric ulcers alone, in most of whom stigmata were recognised despite delay in endoscopy, more than half were over the age of 60 years and $8(50 \%)$ had serious concomitant disease, both factors that might contribute to prolonged bleeding.

Further haemorrhage after admission results in a 12 -fold increase in mortality. " Early identification of those at risk would be helpful. $: 2: 3$ Risk differs according to the lesion $:: 2: 3$ but there is disagreement about the usefulness of such single factors as age, $\mathbf{z}$ serious concomitant disease, fresh haemorrhage, haematemesis $\mathbb{Q}$ rather than melaena, and magnitude of haemorrhage in pre- $C$. dicting rebleeding. $: 2: 3: 29$ Morgan et al $2:$ described a scoring system of "poor prognostic factors" to predict the likelihood of ? rebleeding and death, but we found this unhelpful in our patients? with peptic ulcer, possibly because age and serious concomitant $\frac{\overline{7}}{\bar{D}}$ disease seemed to have less influence in our cases. The use of endoscopic findings in predicting outcome has to our knowledge not been investigated, and our results suggest that stigmata represent a simple means of identifying patients liable to $\vec{O}$ rebleed from peptic ulcer. Early endoscopy, allowing maximum diagnostic yield, is often not possible. Nevertheless, it is worth $\vec{\omega}$ investigating whether the finding of stigmata 24,48 , and more than 48 hours after the onset of bleeding might improve 3 prognosis by helping to select patients with peptic ulcer forearly surgery.

Why are stigmata associated with the likelihood of rebleeding ? Of ulcers without stigmata, some may not have been the source of bleeding, while others may have lost stigmata rapidly, $\vec{v}$ reflecting healing of the bleeding point and a good prognosis. $\omega$ Rapid loss of stigmata has not been documented for a given ulcer, but the pronounced fall in the proportion of duodenal $\Omega$ ulcers bearing stigmata when endoscopy was delayed beyond 123 hours suggests that this is true of some ulcers, although in our series the number of patients endoscoped within 12 hours was $\vec{\theta}$ too small for firm conclusions to be drawn. Beyond 12 hours the $\infty$ proportion with stigmata remained relatively constant. The proportion of gastric ulcers with stigmata was similar at all intervals, and for all patients with peptic ulcers bearing stigmata the risk of further haemorrhage and emergency surgery was independent of the passage of time. Thus stigmata identify those $\mathbb{\Phi}$ ulcers that have definitely bled and seem to have about a $50^{\prime \prime} "$ risk of rebleeding for some days after the initial haemorrhage, in contrast to ulcers without stigmata (of which some have $\vec{J}$ probably never bled), which have a very low risk of rebleeding, similar to that of superficial mucosal lesions. ${ }^{30-33}$ Superficial mucosal lesions probably heal more rapidly than is appreciated and may more easily be missed if no longer bleeding and have no clot attached. ${ }^{34}$

In our patients with varices, bleeding from other sources appeared infrequent. ${ }^{3 i-3 i}$ We could not, however, endoscope $\frac{\delta}{2}$ more than $17\left(48^{\circ}{ }_{11}\right)$ within 24 hours of bleeding, and in more than half stigmata were absent.

Advances in the understanding and management of acute $\mathrm{N}$ upper gastrointestinal haemorrhage are unlikely to be made $>$ unless there is critical use of the best possible methods of identifying the source and assessing the prognosis. Early endoscopy may show that superficial lesions account for a greater proportion of cases than currently accepted even when $\omega$ some other potential bleeding lesion is seen. Failure to apply strict criteria to endoscopic findings may be one reason why increased accuracy in diagnosis has not led to an improvement $\Phi$ in prognosis,,$^{34}$ though death occurs mainly among elderly and + sick patients, in whom it is seldom exclusively due to the gastrointestinal haemorrhage. ${ }^{39} 40$

We thank Sister M Ferguson for invaluable help in running our $\frac{\mathbb{Q}}{\sigma}$ endoscopy service.

Requests for reprints should be sent to Dr K J A Miloszewski.

\section{References}

${ }^{1}$ Cotton, P B, et al, British Medical fournal, 1973, 2, 505.

${ }^{2}$ Forrest, J A H, and Finlayson, N D C, British fournal of Hospital Medicine, $1974,12,160$.

${ }^{3}$ Cotton, P B, and Russell, R C G, British Medical fournal, 1977, 1, 37. 
${ }^{4}$ Haber, I, and Hubens, H, Tijdschrift voor Gastro-Enterologie, 1976, 19, 316.

5 Allan, R, and Dykes, P, Gastrointestinal Endoscopy, 1974, 20, 154.

${ }^{6}$ British Medical Fournal, 1974, 1, 403.

Stevenson, G W, Cox, R R, and Roberts, C J C, British Medical fournal, 1976, 2, 723.

${ }^{\gamma}$ McGinn, F P, et al, Gut, 1975, 16, 707

${ }^{9}$ Hellers, G, and Ihre, T, Lancet, 1975, 2, 1250

10 Allen, H M, Block, M A, and Schuman, B M, Archives of Surgery, 1973, 106, 450 .

${ }^{11}$ Keller, R T, and Logan, G M, jun, Gut, 1976, 17, 180.

12 Myren, J, Scandinavian fournal of Gastroenterology, 1971, suppl No 9, p 67.

3 Dronfield, M w, et al, Lancet, 1977, 1, 1167

14 Hoare, A M, British Medical fournal, 1975, 1, 27.

15 Forrest, J A H, Finlayson, N D C, and Schearman, D J C, Lancet, 1974, 2,394 .

16 Porro, G B, and Petrillo, M, Lancet, 1975, 1, 110.

17 Leinicke, J A, et al, Gastrointestinal Endoscopy, 1976, 22, 228

${ }^{18}$ Fraenkel, G J, and Truelove, S C, British Medical fournal, 1955, 1, 999.

19 Schiller, K F R, Truelove, S C, and Williams, D G, British Medical fournal, 1970, 2, 7 .

3" Johnston, S J, et al, British Medical fournal, 1973, 3, 655.

21 Avery Jones, F, Gastroenterology, 1956, 30, 166.

22 Jones, P F, et al, British Medical fournal, 1973, 3, 660

23 Northfield, T C, British Medical fournal, 1971, 1, 26.
${ }^{24}$ Swinscow, T D V, British Medical fournal, 1976, 2, 513.

${ }^{25}$ Morgan, A G, et al, British Medical fournal, 1977, 2, 237.

${ }^{26}$ Forrest, J A H, and Logan, R F A, British Medical fournal, 1977, 1, 50.

27 Sandlow, L J, et al, American fournal of Gastroenterology, 1974, 61, 282.

${ }^{28}$ Cammock, E E, et al, Archives of Surgery, 1963, 86, 608.

${ }^{29}$ Andersen, D, Klebe, J G, and Nielsen, A, Scandinavian fournal of Gastroenterology, 1968, 3, 537.

30 Khodadoost, J, and Glass, G B J, Digestion, 1972, 7, 129.

${ }^{31}$ Crook, J N, et al, Annals of Surgery, 1972, 175, 771.

${ }^{32}$ Hegarty, M M, Grime, R T, and Schofield, F, British fournal of Surgery, 1973, 60, 275

${ }^{33}$ Foster, D N, Miloszewski, K J A, and Losowsky, M S, Lancet, 1976, 2, 483

${ }^{34}$ Katz, D, et al, American fournal of Digestive Diseases, 1976, 21, 182.

35 Waldram, R, et al, British Medical fournal, 1974, 4, 94.

${ }^{36}$ McCray, R S, et al, American fournal of Digestive Diseases, 1969, 14, 755.

37 Bonanno, C A, Robilotti, J G, jun, and Martel, A J, Gastroenterology, $1972,62,883$.

${ }^{38}$ Cotton, P B, British Medical fournal, 1976, 2, 1197.

${ }^{39}$ Walls, W D, Glanville, J N, and Chandler, G N, Lancet, 1971, 2, 387.

"Allan, R, and Dykes, P, Quarterly fournal of Medicine, 1976, 45, 533.

11 Axon, A T R, and Clarke, A, British Medical fournal, 1975, 1, 491.

\title{
Pituitary-testicular interrelationships in mumps orchitis and other viral infections
}

\author{
D A ADAMOPOULOS, D M LAWRENCE, P VASSILOPOULOS, P A CONTOYIANNIS, \\ G I M SWYER
}

British Medical fournal, 1978, 1, 1177-1180

\section{Summary and conclusions}

Leydig-cell function was assessed in 27 men with acute mumps orchitis by measuring plasma testosterone concentrations before and after the administration of human chorionic gonadotrophin (HCG). The test was also performed on groups of patients with other febrile viral infections and mumps without orchitis and on healthy euspermic men. The concentrations both before and after HCG were significantly lower in patients in the acute phase of mumps-but not in those with other viral infections and mumps without orchitis-than in the healthy men. Basal concentrations of follicle-stimulating hormone (FSH) and luteinising hormone (LH) were significantly increased in patients with acute mumps orchitis, while an exaggerated response to LH-releasing hormone was noted in four patients after the acute phase of the disease. Raised plasma LH concentrations were also found in several patients with viral infections, including mumps without orchitis. There appeared to be no particular merit of any of the treatments used

Endocrine Clinic, “M Eliadi” Hospital, Athens 601, Greece

D A ADAMOPOULOS, DM, consultant endocrinologist

P VASSILOPOULOS, DM, research associate

Endocrine Research Laboratory, University College Hospital Medical School, London WC1E 6DH

D M LAWRENCE, PHD, senior biochemist

G I M SWYER, FRCP, consultant endocrinologist

Hospital for Infectious Diseases, Athens, Greece

P A CONTOYIANNIS, DM, consultant physician (aspirin, prednisolone, and cold baths). In patients reevaluated three to five and 10 to 12 months after the acute phase of their disease the basal testosterone concentrations were similar to those of the healthy men, but several of the patients showed a severely impaired response to HCG. Mean basal FSH and LH concentrations were significantly increased 10 to 12 months after the acute phase, while the mean $L H$ concentration was also raised at three to five months.

It is concluded that mumps orchitis impairs Leydigcell function during the acute phase of the disease but may also have a more permanent damaging effect, similar to that found in the germinal epithelium.

\section{Introduction}

Orchitis is the commonest complication of mumps in postpubertal boys and men and develops in $15-25^{\circ}{ }_{0}$ of patients. Variable degrees of germinal epithelial atrophy occur in half the cases, but since bilateral disease is seen in only $20-25^{\circ}$ of the patients affected ${ }^{12}$ sterility is less common. Though the consequences of mumps orchitis on the tubular system of the testis are well known, ${ }^{3}$ Leydig-cell function during the acute phase and after recovery from the disease has not been documented. We therefore report the results of an assessment of Leydig-cell function, as judged by basal testosterone secretion and its response to human chorionic gonadotrophin (HCG), in patients with mumps orchitis, mumps without orchitis, and other febrile viral infections. Pituitary gonadotrophins were also evaluated, in most cases by measuring basal concentrations of follicle-stimulating hormone $(\mathrm{FSH})$ and luteinising hormone (LH), and in a few by means of an LH-releasing hormone (LH-RH) stimulation test. The effect of the different therapeutic regimens employed in the acute phase of mumps orchitis was also examined. A preliminary account of this study has been given. ${ }^{4}$ 